\title{
Hydrogeological Study of Mangrove Areas Around Guanabara Bay, Rio de Janeiro, Brazil
}

\author{
Gerson Cardoso da Silva Júnior ${ }^{1}$; Carlos Eduardo Braga ${ }^{1,2} \&$ \\ Ingrid de Carvalho Lage ${ }^{1}$ \\ ${ }^{I}$ Av. Jequitibá, 1450, Setor de Geologia de Engenharia e Ambiental Bloco J, sala J0- \\ 005, Departamento de Geologia CCMN - IGEO \\ Cidade Universitária, Campus do Fundão, Rio de Janeiro \\ CEP21949-900e-mail: gerson@acd.ufrj.br. \\ ${ }^{2}$ ENSR-Brasil S.A.
}

\begin{abstract}
The study area covers part of the mangrove belt located around Guanabara Bay, Rio de Janeiro, Brazil. Representing a continental-marine transition, the mangrove ecosystem is very susceptible to environmental variations and impacts. The vegetation cover plays an important role in prevention of erosion and contamination processes in those areas. An ongoing extensive research effort in the Petrochemical Complex of Duque de Caxias, Rio de Janeiro State, Brazil, focuses on the man-induced changes in the physical environment (soils, groundwater flow system, type and volumes of contaminants, geochemical aspects) and the consequences on the neighboring mangrove ecosystem. This article describes the importance of hydrogeological studies in mangrove areas as part of an appropriate environmental assessment, taking as an example an industrial dumping area located in that Petrochemical Complex. Field work included extensive drilling and sampling to obtain basic geological and hydrogeological parameters and data in the pilot area, such as hydraulic conductivity and piezometric heads; emphasizing the tracking of possible contamination by industrial effluents and the marine influence; validation of the conceptual model with mathematical models (numerical and analytical models) was carried out. Results show the great importance of well conducted and detailed hydrogeological studies to properly address environmental problems caused by industrial plants in mangrove areas.
\end{abstract} Keywords: coastal hydrogeology, mangrove hydrology, environmental geology.

\section{Resumo}

A área de estudo cobre parte do cinturão de manguezais localizado ao redor da baía de Guanabara, Rio de Janeiro, Brasil. Representando uma transição continental-marinha, o ecossistema de manguezal é muito suscetível a variações ambientais e seus impactos. A cobertura de vegetação tem um papel importante na prevenção da erosão e processos de contaminação nessas áreas. Realizou-se um esforço de pesquisa extenso e contínuo no Pólo Petroquímico de Duque de Caxias, estado do Rio de Janeiro, Brasil, com foco nas mudanças induzidas pelo homem no ambiente físico (terras, sistema de fluxo subterrâneo, tipo e volumes de contaminantes, aspectos geoquímicos) e as suas conseqüências no ecossistema de mangues vizinho. Este artigo descreve a importância de estudos hidrogeológicos em áreas de mangue como parte de uma avaliação ambiental apropriada, tendo como exemplo uma área de disposição de dejetos industriais localizada naquele Pólo. O trabalho de campo 
incluiu a perfuração de poços e amostragens extensas para obter os parâmetros geológicos e hidrogeológicos básicos em uma area-piloto, como condutividade hidráulica e potenciometria; enfatizou-se a caracterização de possível contaminação por efluentes industriais e o estudo da influência influência marinha; a validação do modelo conceitual foi executada com base em modelos matemáticos (modelos numéricos e analíticos). Os resultados mostram de modo claro a grande importância de realizar estudos hidrogeológicos detalhados para tartar de problemas ambientais causados por instalações industriais em áreas de manguezal de um modo apropriado.

Palavras-chave: hidrogeologia costeira, hidrogeologia dos manguezais, geologia ambiental.

\section{Introduction}

The Petrochemical Complex of Rio de Janeiro, from which toxic waste generation is inherent to its usual activities and processes, is located at the border of an important mangrove forest, extremely impacted in the last decades, with a substantial reduction of the original area. The Guanabara Bay is the main water body in the area, surrounded by the Rio de Janeiro megalopolis, with about 10 million inhabitants, having served as the final destination of great volumes of sewage and industrial effluents for years. Due to a recent and rigorous environmental regulation, industrial activities shall be strictly controlled (Braga, 2001). This study shows the importance of characterizing the wetlands' hydrology for a better understanding of the contamination processes, which will be helpful to plan a future corrective action if necessary. Thus, it is a contribution to the understanding of complex geological environments behavior under environmental stress, in tropical areas. The objectives of the study were to obtain a sound hydrogeological conceptual model of the area, through an extensive field work including hydraulic conductivity tests, water table conditions survey, water quality assessment (evaluation of industrial effluents contamination and marine influence); and validating the conceptual model with a numerical simulation. This will be useful to guide future evaluations of groundwater contamination and remediation actions in this site.

\section{Hydrology of Mangrove Systems}

Occurring at limited latitudes, mangroves show particular characteristics that make these ecosystems both rare and fragile. Its maintenance depends on the perfect balance between several factors such as vegetation, fauna, tidal fluctuations, superficial water and groundwater flow patterns, as well as their chemical and dynamic interactions. 
In the recent past, mangrove forests were taken as pernicious environments to be eradicated for their "unpleasant" visual and sensorial aspects, leading to degradation of an ecosystem with great relevance on the continent-sea equilibrium (Amador \& Amador 1995). Being a transition zone between the continent and the ocean, salty and fresh water, coastal areas contain some of the most biologically productive ecosystems, as the estuaries and, particularly, mangroves (Braga, 2003).

Coastal areas are characterized by the contact between saltwater and freshwater along a diffusion interface in which, due to density differences the heavier saltwater forms a wedge beneath the freshwater (Feitosa \& Manoel Filho, 1997). The study of this interface is a very difficult task, with interfering factors like the presence of coastal lagoons and rivers, dug channels or pumping wells. When dynamic equilibrium is lost, due to man made action (pumping) the penetration of saltwater within the aquifer occurs. Another relevant factor in coastal regions hydrogeology are the tidal oscillations. They exert strong influence on groundwater head and saltwater freshwater interface.

\section{Site description}

The study area is located in the Petrochemical Complex of Rio de Janeiro, at Guanabara Bay's northwest shoreline, Rio de Janeiro, Brazil (Fig. 1). Regionally, the area is a flat- lying coastal plain with an average elevation of 4.5 meters. Bedrock is subexposed in mounds, easily spotted in aerial photos, consisting of pre-Cambrian crystalline rocks (gneisses and migmatites). Quaternary sediments, mainly clays and silts with interbedded sands, surround these morphological features (Amador \& Amador 1995).

The geological environment is characterized by a marine-continental transitional deposition, mainly organic clay lying over sandy or clayey sediments, locally influenced by tidal effects. Some portions of the site may be seasonally submerged, due to the tidal influence. The site lacks a well-defined aquifer system: as stated before, the geological sequence is typical of transitional environments, which make it difficult to define aquifer units. Three layers compose the basic geological sequence, top to bottom: an organic clay layer, fairly continuous, followed by a heterogeneous clayey sandy layer, with many lenses presenting a variety of grading. It can be simply described as a succession of clayey-silty layers, with an overall thickness ranging from 10 


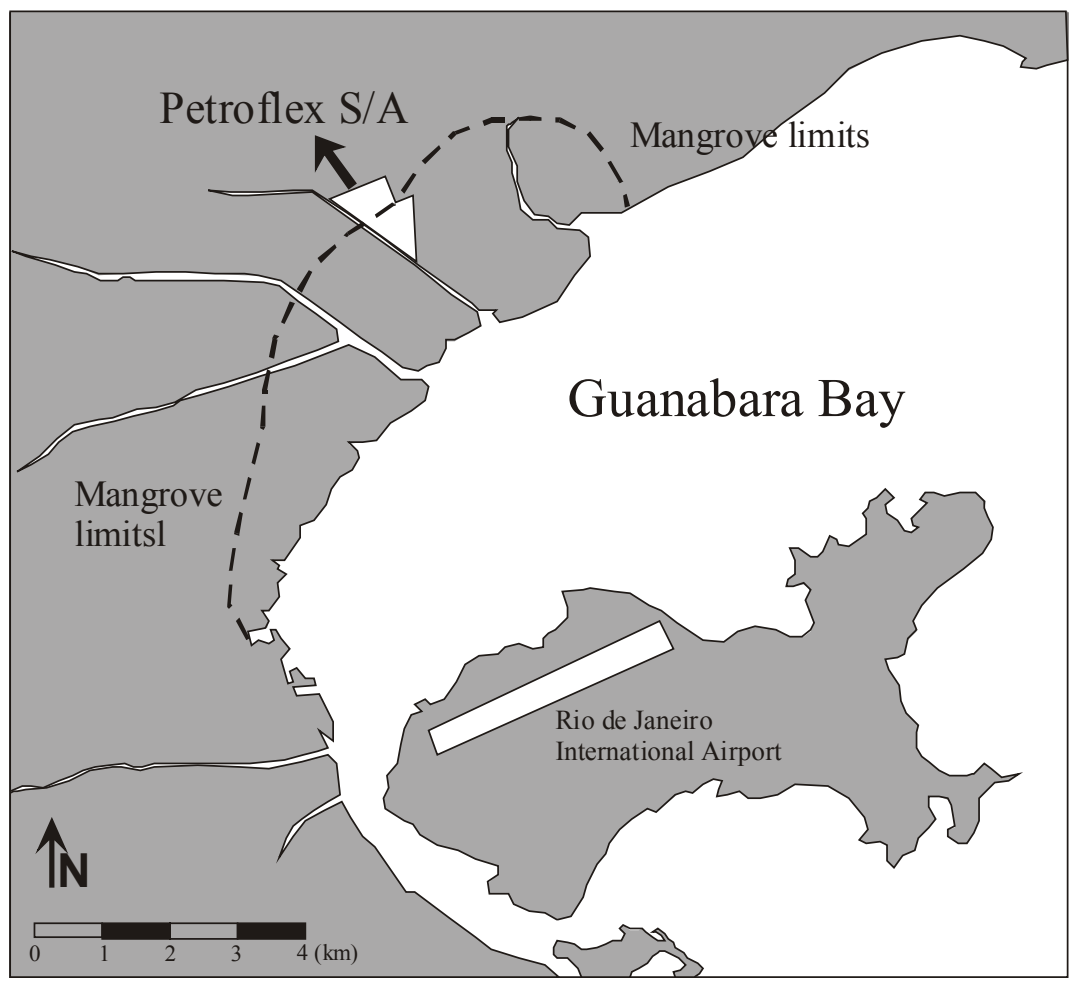

Figure 1 Location of the study area at Guanabara Bay northwestern portion, Rio de Janeiro.

to 15 meters. Lenses composed of medium to coarse sand and gravel occur in this layer, sometimes laterally persistent. The residual soil bottom layer is a sandy layer with small quantities of finer fractions and is the aquifer of the area, sometimes with portions of the layer immediately above. This pattern, with some variations locally, is believed to be recurrent around the mangrove ecosystem of Guanabara Bay.

\section{Methodology}

Studies included hydrochemical and hydrodynamic characterization of groundwater in the mangrove area, with the purpose to subsidize remediation actions in hydrocarbon-contaminated sites. The hydrogeological studies were carried out with a set of piezometers consisting of boreholes installed with depths ranging from 4 to 6 meters and with a 4 in. inner diameter. A series of boreholes were drilled, permitting a continuous monitoring of environmental properties (Fig. 2). The location of each pi- 


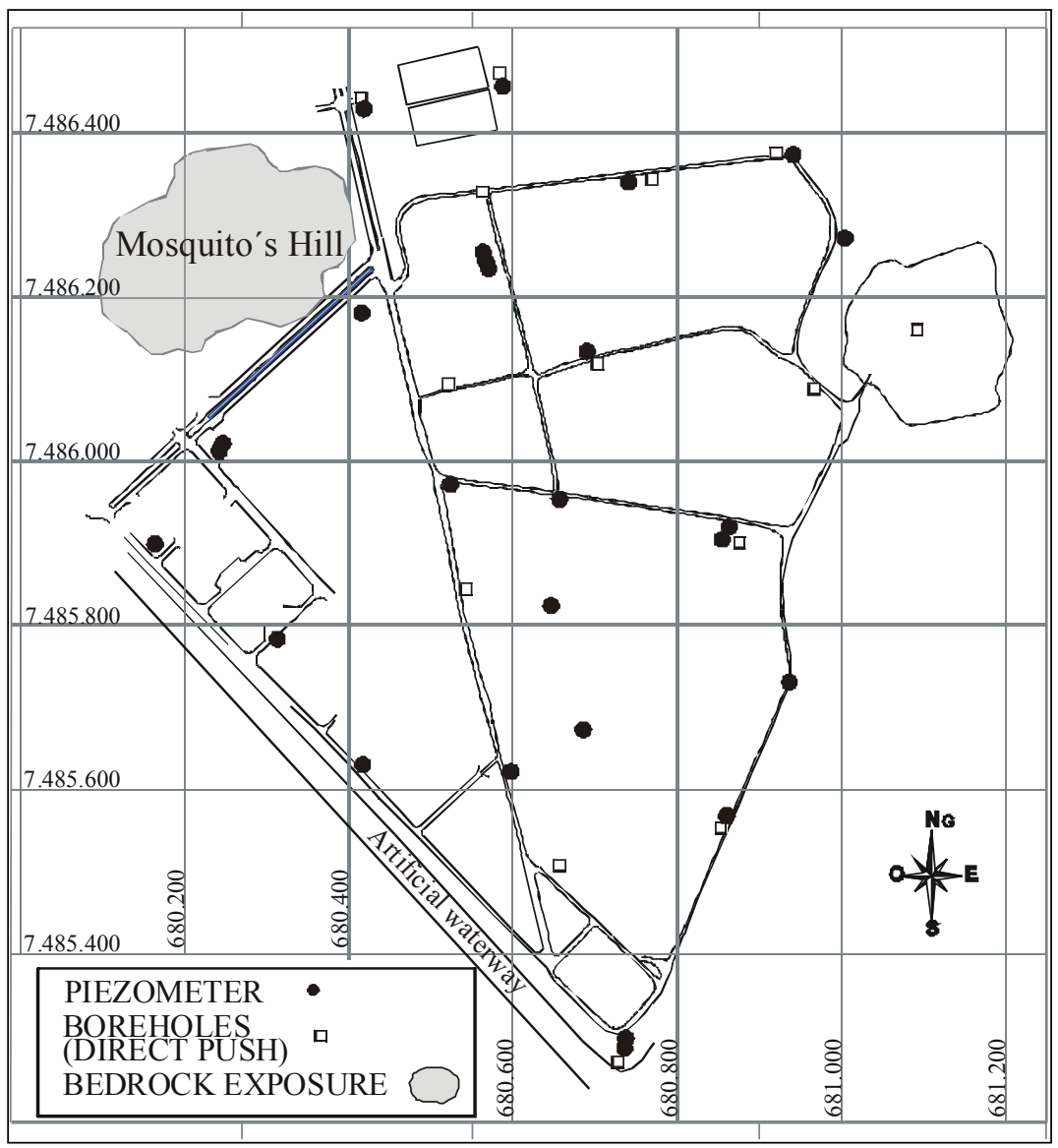

Figure 2 Map showing the piezometers and boreholes where sampling was carried out in the study area. Coordinates in UTM (m)

ezometer was chosen according to criteria such as the proximity to buried tanks or to pipelines containing harmful products that could leak into the environment (Braga 2001). Direct push mechanical soundings were also accomplished in areas where there were no previous subsuperfície information. The data were integrated allowing a relatively detailed geological knowledge of the study area (Braga, 2003).

Groundwater monitoring provided data for an accurate potentiometric map. Surveys were repeated throughout the year, to account for seasonal variations. Hydrochemical analyses resulting from an extensive field sampling survey were also 
carried out. The samples were collected using one pump for every two piezometers, and the pumps were disinfected before each use, in order to avoid crossed contamination. The hydraulic conductivity of the estuarine mud layer was measured via slug and bail tests.

\section{Results and Discussion}

\subsection{Potentiometry}

The potentiometric maps show a radial flow from the hills and elevations to the lower areas (Fig. 3). As those features are the only natural land surface exposed,

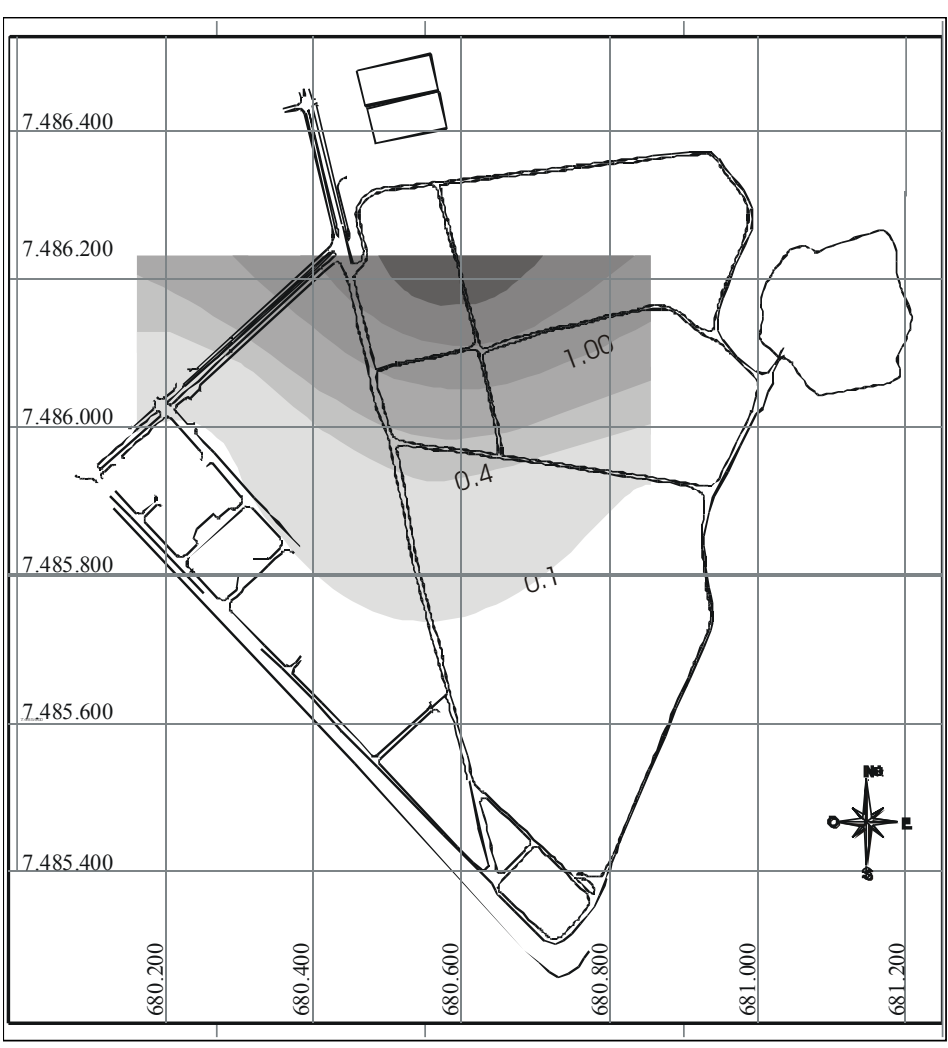

Figure 3 Potentiometric map of the clayey sand horizon in the study area. Darker tones indicate highest water levels. Groundwater flows towards SW. Contour lines in (m). Coordinates in UTM 
they were expected to be the main recharge source to the aquifer, by direct infiltration of rainfall. The results confirm this expectation, with maps resulting from each field survey very similar, showing this recharge-discharge pattern.

\section{Chemical analyses}

The results of chemical analyses revealed a compositional variation depending on the position of the sampling point regarding its proximity to the saltwater canal or to recharge areas. Sodium-chloride type waters are predominantly taken from the estuarine mud layer and near the saltwater bodies. They are more distant from the hills and elevations and, as a consequence, show the most saline waters. Bicarbonate-sodium type waters are sampled in sandy horizons; the true aquifer layers correspond to those areas, where groundwater flows to relatively larger distances, horizontally. Bicarbonate-magnesium type waters come from clayey layers or from the residual soil, corresponding to the bottom of the sedimentary profile, although, due to its more permeable character, apparently has a direct connection with recharge areas (hills and plateaus). As a consequence, this water type is the one with more diluted water, as it has a direct intake of the rainfall. The resulting hydrogeochemical framework can be interpreted as a product of the local geological conditions.

\section{Hydraulic Conductivity}

Hydraulic conductivity of the estuarine mud layer was obtained with slug and bail field tests. Using the Hvorslev solution for slug/bail tests, the mean hydraulic conductivity was estimated to be about $10^{-4} \mathrm{~cm} / \mathrm{s}$ for the silty sand in a preliminary research (Braga, 2001). This relatively high value was believed to come from the preferential paths formed with the framework of fragments of plants and shells often found within this layer, mixed with the sediments. Later on, the average values of hydraulic conductivity obtained through slug tests were: $9,6.10^{-6}$ for the organic clay, $8,7.10^{-6}$ for the silty sand and $1,63 \cdot 10^{-4}$ for the residual soil. There is a coherence of the values obtained with those expected for each horizon, except the silty sand horizon. That value probably expresses the strong influence of finer domains in the interbedded layers of that package, which limit the hydraulic conductivity values. Besides the hydraulic conditions, it shows there are several sandy lenses without connection amid the clayeysandy package (Lage, 2002). 


\section{Contamination Aspects}

When contamination aspects are considered, groundwater in the study area seems to be preserved, as far as it could be assessed. The artificial landfill, which is present in part of the area together with the upper portion of the natural soil, forms a thick layer with a low permeability, that prevents surface contamination from reaching the aquifer system.

Eventually, some of the analyzed parameters have shown concentrations above those established by the Brazilian Environmental Authority for those conditions.

\section{Numerical simulation}

Groundwater flow simulations were performed with the objective to assess the relevance of the geological framework in flow patterns and in order to confirm the results obtained from the field survey. The system was modeled with the use of the three-dimensional finite difference code Visual Modflow ${ }^{\circledR}$ considering the steady-state condition. The model-input parameters were with the field surveys and laboratory tests for estimation of hydraulic conductivity. The results were calibrated according to the water gauging in the piezometer net. Different hypotheses concerning the conceptual model were tested, the most satisfactory showing a similar arrangement of radial flow from the hills surroundings to the remaining portions of the site.

\section{Conclusions}

The hydrogeological study developed at the Rio de Janeiro Petrochemical Complex shows the great influence of hills and plateaus that outcrop in the coastal plain in the groundwater flow system of the area. The numerical simulation helped to improve the hydrogeological conceptual model. That is useful to planning and environmental management purposes.

The geological investigation showed that the stratigraphy of the area is quite complex, characteristic of mangroves areas. The stratigraphic setting is characterized by interbedded sandy and silty layers, beneath a continuous layer of organic clay. That sequence was deposited on a bedrock of quite irregular surface. The layers present a lateral continuity towards Guanabara Bay, due to the sea transgressions and regressions that created the sedimentary package. 
The hydraulic conductivities obtained for the three horizons of interest were consistent with the constituent materials, showing that the planning and installation of the wells, as well as the execution of the slug tests was accomplished satisfactorily.

The monitoring of the water level made viable the hydraulic behavior characterization. The electric conductivity survey seems to have a seawater influence in the study area, through the channel and due to periodic flood by the tides.

\section{References}

Amador, E.S \& Amador, A.B., 1995. Cenários Paleogeográficos da Baía de Guanabara. Annals In: V CONGRESS OF ASSOCIAÇÃO BRASILEIRA DE ESTUDOS DO QUATERNÁRIO (ABEQUA) AND XI SIMPÓSIO DE SEDIMENTOLOGIA COSTEIRA: 65-72.

Braga, C.E. 2001. Diagnóstico das Condições Hidrogeológicas da Área Industrial Ativa da Petroflex S.A. INTERNAL REPORT. Petroflex Ind. e Com. S.A.: $1-78$.

Braga, C.E. 2003. Caracterização Hidroquímica e Hidrodinâmica das Águas Subterrâneas em Área de Manguezal da Baía de Guanabara, RJ. 2003, 146 p. (Dissertação de Mestrado, Programa de Pós-Graduação em Geologia, Universidade Federal do Rio de Janeiro, Rio de Janeiro).

Feitosa, F. A. C. \& Manoel Filho, J. 1997. Hidrogeologia: Conceitos e Aplicações. Fortaleza: CPRM, LABHID-UFPE. 391 p.

Infante, E. D. L. 2002. La influencia de las mareas oceánicas en los acuíferos de Cayo Largo del Sur, Cuba. In: CONG. INTERNACIONAL DE HIDROGEOLOGÍA, XXXII. Mar del Plata.

Lage, I.C. 2002. Caracterização geológica e hidrogeológica de uma área de manguezal em indústria petroquímica. 104p. (Monografia Graduação em Geologia Departamento de Geologia, Universidade Federal do Rio de Janeiro, Rio de Janeiro). 